\title{
PROFIL KESESUAIAN PERESEPAN OBAT GENERIK DENGAN FORMULARIUM RUMAH SAKIT PADA PASIEN BPJS PENYAKIT JANTUNG KORONER RAWAT JALAN DI RSU KABUPATEN TANGERANG PERIODE FEBRUARI-JUNI 2019
}

\section{PROFIL OF THE SUITABILITY OF GENERIK DRUGS PRESCRIBING WITH HOSPITAL FORMULARY IN PATIENTS WITH OUTPATIENT CORONARY HEART DISEASE IN GENERAL HOSPITAL IN TANGERANG DISTRICT FEBRUARY-JUNE PERIOD 2019}

\author{
Ristiana Della ${ }^{1 *}$, Nita Rusdiana ${ }^{1}$ \\ ${ }^{1}$ Sekolah Tinggi Farmasi Muhammadiyah Tangerang \\ *Corresponding Author Email : ristianadella04@gmail.com \\ DOI: http://dx.doi.org/10.47653/farm.v7i2.301
}

\begin{abstract}
ABSTRAK
Pemerintah RI telah mengeluarkan Permenkes RI No. HK.02.02/MENKES/068/I/2010 yang mewajibkan penulisan resep dengan nama generik di Fasilitas Pelayanan Kesehatan Pemerintah untuk mengantisipasi tingginya harga obat. Formularium Rumah Sakit merupakan daftar obat yang disepakati staf medis, disusun oleh Komite Farmasi dan Terapi yang ditetapkan oleh pimpinan rumah sakit. Formularium bermanfaat sebagai acuan bagi penulis resep, mengoptimalkan pelayanan kepada pasien, memudahkan perencanaan, dan penyediaan obat pada fasilitas pelayanan kesehatan. Penelitian dilakukan di RSU Kabupaten Tangerang. Penelitian ini bertujuan untuk mengukur persentase penulisan resep dalam nama generik dan kesesuaian dengan Formularium Rumah Sakit pada pasien BPSJ penyakit jantung koroner rawat jalan di RSU kabupaten Tangerang periode Februari-Juni 2019. Metode penelitian ini menggunakan metode deskriptif dengan data yang dikumpulkan secara retrospektif. Hasil penelitian menunjukkan bahwa rata-rata persentase penulisan resep dengan nama generik periode bulan Februari-Juni 2019 sebesar 66,7\% dan persentase penulisan resep dengan Formularium Rumah Sakit rata-rata sebesar 7,28\%. Penulisan resep pasien BPJS penyakit jantung koroner rawat jalan di poli jantung RSU Kabupaten Tangerang belum sesuai dengan PerMenKes RI No. HK.02.02/MENKES/068/I/2010 dan Formularium RSU Kabupaten Tangerang Tahun 2018.
\end{abstract}

Kata Kunci: BPJS Kesehatan, Formularium Rumah Sakit, Resep Obat Generik

\section{ABSTRACT}

The Indonesian government has issued RI regulation NO. HK. 02.02/MENKES/068/I/2010 which requires writing prescriptions with generik names in government health service facilities to anticipate drug prices. Hospital formulary is a list of drugs agreed upon by medical staff, compiled by the pharmaceutical and therapy committee established by the hospital leadership. The formulary is useful as a reference for prescribers, optimizing services to patients, facilitating planning, and providing medicines in health care facilities. The study was conducted at the Tangerang District General Hospital. This study aims to measure the percentage of prescription writing in generic names and compliance with hospital formularies in BPJS patients for outpatient coronary heart disease in Tangerang District in the February-June 2019 period. This research method uses descriptive methods with data collected retrospectively. The results showed that the average percentage pf prescription writing with generic names for the February-June 2019 period was 66,7\% and the percentage of prescription writing with hospital formularies was $7,28 \%$. Writing prescriptions for BPJS patients for outpatient coronary heart disease at the heart polyclinic of Tangerang District General Hospital is not in accordance with PerMenKes RI No. HK. 02.02/MENKES/068/I/2010 and Formulary of Tangerang District General Hospital in 2018.

Keywords: BPJS Health, Hospital Formulary, Generic Prescription Drug

\section{PENDAHULUAN}

Obat generik merupakan obat yang apabila nama patennya habis masa berlakunya, maka perusahaan farmasi lain dapat memasarkan obat tersebut. Dalam hal ini obat tidak diberi nama paten lagi, melainkan dipasarkan dengan nama generiknya, yaitu 
nama umum yang ditetapkan oleh Organisasi Kesehatan Dunia (WHO) (Yusuf, 2016).

Formularium Rumah Sakit merupakan daftar obat yang disepakati staf medis, disusun oleh Komite Farmasi dan Terapi yang ditetapkan oleh pimpinan rumah sakit. Formularium Rumah Sakit harus secara rutin dievaluasi sesuai kebijakan dan kebutuhan rumah sakit. Untuk meningkatkan kepatuhan terhadap Formularium Rumah Sakit, maka rumah sakit harus memiliki kebijakan dalam menambah dan mengurangi obat dalam Formularium Rumah Sakit dengan mempertimbangkan indikasi penggunaan, efektivitas, rasio, dan biaya (Permenkes RI, 2016).

Pasien BPJS merupakan pasien yang berkunjung ke rumah sakit dengan menggunakan jaminan kesehatan Badan Penyelenggaraan Jaminan Sosial (BPJS), dengan demikian pasien BPJS adalah pasien yang tidak membayar sendiri melainkan pasien yang jasa pelayanan kesehatan dan penebusan obatnya ditanggung oleh pemerintah. Pola peresepan dan penggunaan obat generik yang di peruntukan untuk pasien BPJS biasanya lebih sempit baik dari jenis, harga maupun merk dagang. Hal ini dikarenakan pasien BPJS terikat oleh Daftar dan Plafon Harga Obat (DPHO). Dokter biasanya tidak leluasa dalam meresepkan obat dan ada kemungkinan untuk selalu meresepkan obat generik (Permenkes RI, 2016).

Tahun 2016 World Health Organization (WHO) mencatat bahwa terdapat 56,9 juta kematian diseluruh dunia, dimana penyakit jantung iskemik dan stroke merupakan pembunuh terbesar di dunia dengan 15,2 juta kematian. Penyakit ini merupakan penyebab kematian tertinggi di dunia dalam 15 tahun terakhir (WHO, 2018).

Berdasarkan penelitian yang dilakukan oleh Lilis Suryani tahun 2015 dengan judul "Profil Peresepan Obat Generik Sesuai Formularium Rumah Sakit Pada Pasien Poli Paru Rawat Jalan BPJS di RSUD dr. Adjidarmo Kab. Lebak Periode Juni 2015" mengatakan bahwa dari 1152 obat dalam 240 resep. Terbagi dalam dua kategori yaitu kategori Formularium Rumah Sakit dan Non Formularium Rumah Sakit. Dimana obat yang termasuk kedalam kategori Formularium Rumah Sakit lebih banyak digunakan di RSUD dr.Adjidarmo dibandingkan dengan kategori obat yang termasuk kedalam kategori non
Formularium Rumah Sakit. Obat dalam kategori Formularium Rumah Sakit sebanyak $85,6 \%$ sedangkan obat yang tidak termasuk kedalam kategori Non Formularium Rumah Sakit sebanyak 14,4\% (Suryani, 2015).

\section{METODE PENELITIAN}

Penelitian ini termasuk jenis penelitian non eksperimental yang bersifat deskriptif dengan data yang dikumpulkan secara retrospektif tentang kesesuaian resep pasien BPJS penyakit jantung koroner rawat jalan di Poli Jantung RSU Kabupaten Tangerang Tahun 2019. Pengambilan sampel dilakukan secara acak (random sampling).

\section{Alat}

Alat yang digunakan dalam penelitian ini adalah form pengumpulan data sebagai catatan hasil peresepan obat generik di rekam medik pasien BPJS penyakit jantung koroner rawat jalan.

\section{Bahan}

Bahan yang digunakan dalam penelitian ini adalah Formularium RSU Kabupaten Tangerang Tahun 2018.

\section{Metode}

Teknik pengambilan sampel dalam penelitian ini menggunakan metode acak (system random sampling). Pengumpulan data penelitian dari hasil catatan registrasi rekam medik pasien BPJS rawat jalan di poli jantung RSU Kabupaten Tangerang periode FebruariJuni 2019.

\section{HASIL DAN PEMBAHASAN \\ Persentase Obat Jantung dengan Nama Generik dan Non Generik}




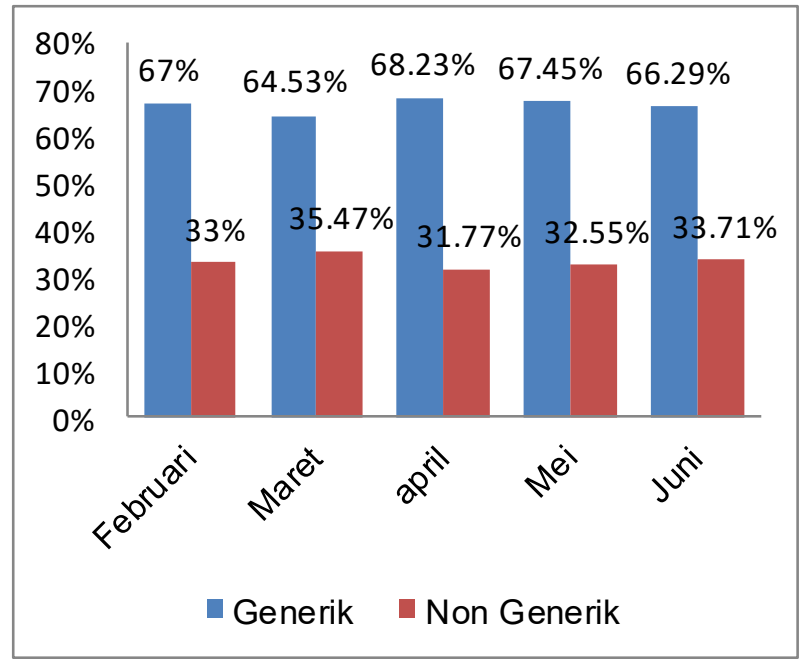

Gambar 1.Grafik Persentase Obat Jantung dengan Nama Generik dan Non Generik

Berdasarkan hasil penelitian dapat dilihat bahwa persentase obat jantung dengan nama generik pada pasien BPJS penyakit jantung koroner rawat jalan di RSU Kabupaten Tangerang yang didapat pada bulan Februari $67 \%$, bulan Maret $64,53 \%$, bulan April $68,23 \%$, bulan Mei $67,45 \%$ dan bulan Juni $66,29 \%$. Persentase obat jantung dengan nama generik paling tinggi pada bulan April dengan persentase $68,23 \%$.

Hasil penelitian menunjukkan bahwa penulisan resep BPJS dan penggunaan obat generik di RSU Kabupaten Tangerang belum sesuai dengan yang ditentukan dalam Permenkes $\mathrm{RI}$ No.HK.02.02/MENKES/068/I/2010 tentang Kewajiban Menggunakan Obat Generik di Fasilitas Pelayanan Kesehatan Pemerintah. Kemenkes telah mengeluarkan pernyataan pada tahun 2010 bahwa pada tahun 2014, 80$90 \%$ resep dari dokter di rumah sakit umum pemerintah atau puskesmas harus obat generik. Tetapi dari hasil penelitian yang dilakukan dari bulan Februari-Juni 2019 terlihat bahwa pelaksanaan penulisan resep dengan nama generik hanya mencapai $66,7 \%$. Permasalahan yang sering terjadi adalah pemberian atau peresepan obat dengan nama dagang.

Sebagai implementasi UU No 40 tahun 2004 tentang Sistem Jaminan Sosial Nasional (SJSN), dibentuk Badan Penyelenggara Jaminan Sosial yang terdiri dari BPJS Kesehatan dan BPJS Ketenagakerjaan. BPJS Kesehatan mulai beroperasi tanggal 1 Januari 2014. Dengan keberadaan institusi baru ini, tingkat pelayanan kesehatan mengalami perubahan paradigma dari semula pelayanan berbasis fee for service (tarif per tindakan) menuju ke managed care yang bertumpu pada pembayaran prospektif. Dengan adanya BPJS maka sistem pembayaran berubah menjadi asuransi sehingga pasien tidak perlu merogoh kantong untuk membayar jasa medis dokter (Tanner, dkk., 2015).

\section{Persentase Kesesuaian Peresepan Obat dengan FRS}

Persentase kesesuaian peresepan dengan Formularium Rumah Sakit pada pasien BPJS penyakit jantung koroner rawat jalan di RSU Kabupaten Tangerang periode Februari-Juni 2019 dapat dilihat pada grafik dibawah ini:

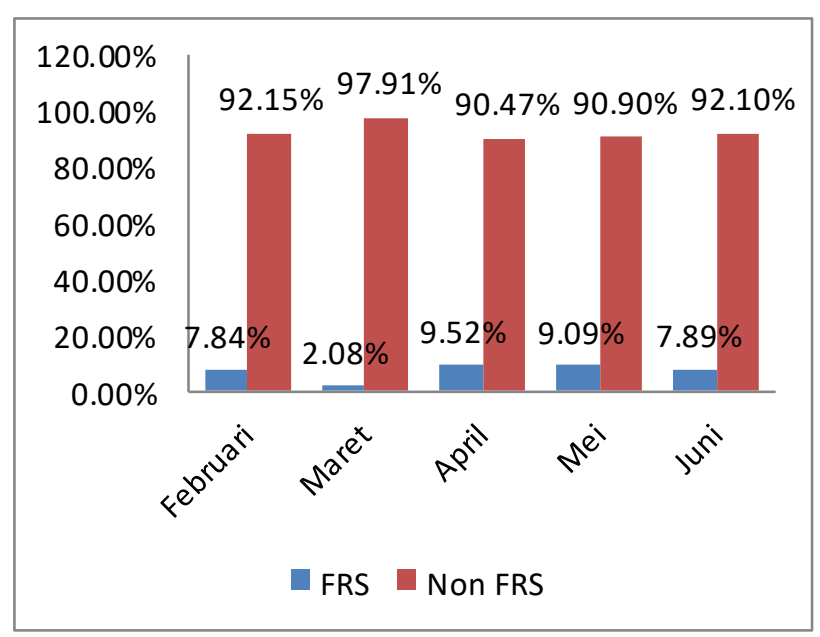

Gambar 2.Grafik Persentase Kesesuaian Peresepan Obat dengan FRS

Hasil yang didapat dari 5 bulan yang diteliti belum sesuai standar yang ditentukan oleh pemerintah dalam indikator Pelayanan Minimal Rumah Sakit yaitu 100\%. Persentase kesesuaian peresepan obat dengan Formularium Rumah Sakit pada pasien BPJS penyakit jantung koroner rawat jalan di RSU Kabupaten Tangerang yang didapat pada bulan Februari sebesar 7,84\%, bulan Maret sebesar 2,08\%, bulan April sebesar 9,52\%, bulan Mei sebesar 9,09\%, dan bulan Juni sebesar 7,89\%. Persentase kesesuaian peresepan obat dengan Formularium Rumah Sakit paling tinggi pada bulan April dengan persentase 9,52\%. Hasil rata-rata dari persentase kesesuaian peresepan obat dengan Formularium Rumah Sakit pada periode bulan Februari-Juni 2019 yang didapat sebesar 7,28\%. Hal tersebut disebabkan karena resep obat yang diberikan oleh doker pada pasien BPJS penyakit jantung koroner 
rawat jalan di poli jantung RSU Kabupaten Tangerang periode bulan Februari, Maret, April, Mei dan Juni seperti Aspilet, Brilita, Aldacton, Miniaspi, Concor, Nitrokaf, Lasix, Adalat oros, dan Herbesser tidak termasuk dalam Formularium RSU Kabupaten Tangerang Tahun 2018.

Srategi pembuatan Formularium Rumah Sakit melibatkan para profesional kesehatan dengan dasar menjamin ketersediaan obat yang berkualitas dengan harga yang terjangkau, yaitu efektif dan efisien. Demikian pula untuk sosialisasi dan evaluasi kualitas Formularium Rumah Sakit dilakukan pertemuan rutin bulanan. Namun demikian hasil penelitian menunjukkan persentase kesesuaian resep pasien BPJS penyakit jantung koroner rawat jalan di RSU Kabupaten Tangerang yang ditulis dalam resep dengan Formularium Rumah Sakit masih sangat rendah, yaitu hanya mencapai $7,28 \%$. Ada tiga faktor yang terkait dengan ketidak sesuaian penulisan resep dengan Formularium Rumah Sakit, yaitu faktor dokter, faktor pasien dan faktor obat. Faktor pertama, keputusan dokter untuk menuliskan obat pada resep dipengaruhi oleh pendidikan yang diperoleh, informasi yang diterima dari sejawat, lingkungan tempat kerja dan industri farmasi, serta interaksi dengan pasien. Faktor kedua, pasien mempunyai keluhan dan keinginan, serta sebagai pihak yang membayar dapat mempengaruhi penulisan resep dokter sebagai pengambil keputusan tentang obat yang akan digunakan sesuai dengan diagnosis yang ditegakkan. Faktor ketiga, obat merupakan produksi industri farmasi, dimana pihak industri farmasi berperan mengiklankan produknya kepada dokter agar dokter mau menggunakannya (Supardi, dkk 2005).

\section{KESIMPULAN}

Berdasarkan hasil penelitian yang telah dilakukan dapat disimpulkan bahwa:

1. Penulisan resep obat dengan nama generik pada pasien BPJS penyakit jantung koroner rawat jalan di RSU Kabupaten Tangerang periode Februari-Juni 2019 yaitu sebanyak 704 obat dengan rata-rata $66,7 \%$ dari total keseluruhan obat generik-non generik 1058 obat, Peresepan obat generik tersebut belum sesuai dengan Permenkes RI No.HK.02.02/MENKES/068///2010.

2. Resep obat yang sesuai dengan Formularium Rumah Sakit pada pasien BPJS penyakit jantung koroner rawat jalan di poli jantung RSU Kabupaten Tangerang periode Februari-Juni 2019 yaitu sebanyak 16 resep dengan rata-rata $7,28 \%$ dari total keseluruhan 223 resep.

\section{DAFTAR PUSTAKA}

Kemenkes RI. 2010. Kementerian Kesehatan Republik Indonesia. Pedoman Penyususnan Formularium Rumah Sakit. Jakarta.

Nafsiah. 2013. Menteri Kesehatan Republik Indonesia Nomor 328/MENKES/SKVIII/2013 tentang Formularium Nasional. Jakarta.

Pemenkes RI. 2016. Peraturan Menteri Kesehatan Republik Indonesia Nomor 52 Tahun 2016 tentang Standar Tarif Pelayanan Kesehatan dalam Penyelenggaraan Program Jaminan Kesehatan. Jakarta.

Permenkes RI. 2016. Peraturan Menteri Kesehatan Republik Indonesia Nomor 72 Tahun 2016 Tentang Standar Pelayanan Kefarmasian di Rumah Sakit. Jakarta.

Permenkes RI. 2014. Peraturan Menteri Kesehatan Indonesia Nomor 58 tahun 2014 Tentang Standar Pelayanan Kefarmasian di rumah sakit. Jakarta Indonesia. Jakarta.

Permenkes RI. 2010. Peraturan Menteri Kesehatan Republik Indonesia Nomor HK. 02.02/MENKES/068/I/2010 Tentang Kewajiban Menggunakan Obat Generik di Fasilitas Pelayanan Kesehatan Pemerintah. Jakarta.

Perpres. 2018. Peraturan Presiden Republik Indonesia Nomor 82 Tahun 2018 Tentang Jaminan Kesehatan. Jakarta.

Supardi, S., Azis, S., Herman, M. J., Jamal, S., Mun, A., Farmasi, P., Litbangkes, B., \& Ri, D. 2005. Biaya Tambahan Yang dibayar Pasien Rawat Jalan Akibat Penulisan Resep Tidak Sesuai Dengan Formularium Rumah Sakit. II(1): 43-50.

Suryani, L. 2015. 'Profil Peresepan Obat Generik Sesuai Formularium Rumah Sakit Pada Pasien Poli Paru Rawat Jalan BPJS di RSUD dr. Adjidarmo Kab. Lebak Periode Juni 2015'. Tangerang: Sekolah Tinggi Farmasi Muhammadiyah Tangerang.

Syamsuni. 2006. Ilmu Resep Jakarta : Penerbit Buku Kedokteran EGC.

Tanner, A. E., \& Ranti, L., \& Lolo, W. A. 2015. Evaluasi Pelaksanaan Pelayanan Resep Obat Generik pada Pasien BPJS Rawat 
Jalan di RSUP. Prof . dr. R . D . 4(4): 5864.

Tjay, T., \& Rahardja, K. 2015. Obat-Obat Penting Khasiat, Penggunaan dan Efekefek Sampingnya. Jakarta.

WHO. 2018. World Health Organization. Retrieved September. 9. 2018. from http://www.who.int/news-room/factsheets/detail-the-top-10-causes-of-death. Yusuf, F. 2016. Studi Perbandingan Obat Generik dan Obat dengan Nama Dagang. 1(1): 5-10. 